\title{
Dagshistorie 1909.
}

Tildragelser vedrarende Nordslesvig, optegnede efter Tidsfølgen.

2. Januar. Forsamlingshuset i Bevtoft, der er blevet ombygget og udvidet, indvies.

3. Januar. Selskabelig Forening for Hjortkær og Bjolderup Sogne oprettes.

10. Januar. Et Møde, som „Foredragsforeningen for Flensborg og Omegn" vil afholde i Padborg Kro, opleses af Amtsforstanderen, fordi Forhandlingerne føres paa Dansk.

Gaardejer Karsten Gregersen i Frøslev faar af Landraaden i Flensborg Tilhold om ufortovet at nedlægge sine Poster som stedfortrædende Amtsforstander oo Civilstandsembedsmand, fordi han har villet deltage $i$ det nævnte danske Foredragsmøde i Padberg.

11. Januar. Landsretten i Flensborg frikender som Følge af Mangel paa Bevis Gaardejer C. Ravn fra Løndt for paa en Køretur i Kogene at have forhaanet et tysk Flag. (Jf. 11. Novbr. 1908.)

14. Junuar. Et Møde, som „Foredragsforeningen for Flensborg og Omegn" vil afholde i Flensborg og som er besøgt af 300 Mænd og Kvinder, opløses af Politiet af samme Grund som Mødet i Padborg d. 10. Januar.

16. Januar. Landsretsraad Dr. Hahn foretager "en Storm paa Tønder", idet han der i Byen afholder et Møde, paa hvilket det vedtages at gøre Indsigelse imod den Beslutning, som Tønder Byraad tog den 22. December 1908. Der dannes en ny stedlig Afdeling af "Den tyske Forening “, og der tegner sig til. denne 260 Medlemmer, hvoraf dog 200 er Embedsmænd og Seminarister. 
22. Januar. I den tyske Rigsdag paataler Rigsdagsmand H. P. Hanssen Oplesningen af de to Foreningsmøder i Padborg og Flensborg (jf. 10. og 14. Januar). Han hævder, at Haandhævelsen af den nye Foreningslov i Nordslesvig mange Steder giver Anledning til Uklarhed og Forvirring. Myndighedernes Adfærd i Flensborg Amit er aldeles ugrundet og indeholder en dybt krænkende Haardhed mod den rolige og fredelige Befolkning. Statssekretær Bethmann Hollweg beklager, at han endnu ikke kan tage Standpunkt til Sagen, da han savner Akterne.

26. Januar. Bankbestyrer Jørgen Møller i Skærbæk faar Ordre til at være ude af Landet i Lobet af en Maaned, fordi han er "falden til Besvær ${ }^{4}$ ved at overvære et politisk Møde.

29. Januar. Landsretten i Flensborg nedsætter en Bøde paa 50 Mark, som Skovrider Plaas i Sønderskoven ved Sønderborg er bleven idømt for Fornærmelse imod Gaardejer Peter Kaad i Vollerup, til 5 Mark. (Jf. 5. August 1908).

2. Februar. Landdagsmand, Gehejmeraad Chr. J. Jürgensen i Husum afgaar ved Døden under et Ophold i Berlin. (Født d. 6. Marts 1838 i Stubbæk ved Aabenraa). Trods sit udprægede tyske Sindelag var han $i$ de senere Aar en afgjort Modstander af "Den tyske Forening". (Jf. 5. Oktober 1908).

6. Februar. „Den tyske Forening" vedtager paa et $\mathrm{Be}$ "styrelsesmøde i Rødekro bl. a. følgende Krav: Udvisningerne skal genoptages, der skal nægtes danske Indersaatter Bosættelsestilladelse, Fortyskningen bør støttes ved en Millionbevilling, og fra Berlin bor der oves et Pres paa den danske Regering i Retning af, at de Folkehøjskoler, der faar Statstilskud, ikke maa optage nordslesvigske Elever, samt at der oprettes danske Konsulater i Flensborg og Kiel.

12. Februar. Forsamlingshuset i Spandet indvies.

22. Februar. I den prøjsiske Landdag retter Landdagsmand Nis Nissen en Forespørgsel til Landbrugsminister Arnim i Anledning af, at Landbrugskamret for Hertugdømmerne har nægtet at udbetale en Præmie, der er bleven tilkendt 
en Optant. - Ministeren lover at undersøge Sagen.

Gaardejer Bunde Martensen Refslund i Bovlund afgaar ved Døden. Han hørte til de nstille "i Landet; han var ikke af dem, der gaar foran, men han var med i meget. Paa sit sidste Sygeleje ydede han et frivilligt Bidrag paa 1000 Mark til hver af vore tre nationale Foreninger.

26. Februar. Landsretten i Flensbory stadfæster en Bøde paa 50 Mark, som Redaktør A. Svensson i Sønderborg var bleven idømt for Fornærmelse mod Skovrider Plaas i Sønderskoven ved Sønderborg. (Jf. 9. December 1908).

27. Februar. I den prøjsiske Landdag indledes anden Behandling af Indenrigsministeriets Budget med en Forhandling om det nordslesvigske Spørgsmaal. - Tre Landdagsmænd, den nationalliberale Dr. Schifferer, den frikonservative Johannssen og den konservative Grev Reventlow, optræder som den tyske Forenings Talsmænd. - Indenrigsminister Moltke udtaler, at den ventede Beroligelse efter Optanttraktaten ikke var indtraadt, og han lover Tyskerne Støtte. - Landdagsmand Kloppenborg Skrunnsager tilbageviser djærvt de tyske Angreb; han omtaler Gehejmeraad Jürgensens Artikler som et Vidnesbyrd fra en Mand, der paa Grundlag af sine Erfaringer har raadet til en forsonlig Politik (jf. 5. Oktober 1908); han betegner Tyskernes Nødraab som aldeles ugrundede og hævder, at de danske Nordslesvigere ikke driver landsforræderske Bestræbelser. - Efter at Grev Moltke fra Uetersen derpaa har talt imod Danskerne, sluttes Drøftelsen, hvorved Landdagsmand Nis Nissen bliver afskaaren fra Ordet.

3. Marts. Bisidderretten i Nordborg idemmer den ansvarhavende Redakter af "Sonderburger Zeitung", E. Kühler, en Bøde paa 10 Mark for at have fornærmet Journalist Andreas Grau. - Retten begrunder den milde Dom med, at tyske Redaktører altid angribes af den danske Presse.

12. Marts. Landbrugskamret i Kiel vedtager at tegne 25 Andele à 1000 Mark til et slesvig-holstensk Bosættelsesselskab. Forslaget begrundes med, 
at man dels vil befolke Landet mere og dels om muligt forhindre Danskernes Indtrængen i Nordslesvig". (Jf. 28. Maj).

13. Marts. Bisidderretten i Sønderborg idømmer Journalist Andreas Grau i Nordborg en Bøde paa 150 Mark for $i$ en Artikel i "Dybbøl-Posten" at have fornærmet en gammel Hjemmetysker, Gaardejer Eriksen i Lunden paa Als, der under Mærket „En gammel Alsinger “ har skrevet om danske Forhold i "Sonderb. Ztg." Gaardejer A. C. Lau i Stenderup ved Toftlund afgaar ved Døden. (Født d. 21. Novbr. 1834). Han var en bramfri og trofast dansk Mand, der blev betroet med en Række Tillidshverv.

16. Marts. Den tyske Højskoleforening holder Aarsmøde i Tinglev. Det oplyses, at den derværende nye Højskolebygning har kostet 90,000 Mark, hvoraf Provinsen har skænket 5,000 og Staten 6,000 Mark. Foreningen faar en aarlig Statshjælp paa 1500 Mark. Man drøfter Oprettelsen af en Højskole i Nordborg.

18. Marts. Overforvaltningsretten i Berlin stadfæster ot Afslag, som Distriktsudvalget i Slesvig har givet Tandlæge J. Smith i Haderslev paa dennes Ansøgning om at faa Vandrenæringsbovis til Udbredelse af den blaa Sangbog. Afslaget begrundes under Henvisning til Forordningen af 1866 om Afsætning af ophidsende" Viser".

21. Marts. Ved Provinslanddagens Festmiddag holder Overpræsident v. Bülow i Prins Heinrichs Nærværelse en Tale, der ved sin truende Tone afviger betydeligt fra hans bekendte Haderslevtale. Han vender sig bl. a. imod "de mange Kræfter ${ }^{\text {, der }}$ "paa vor Side af Kongeaaen aabent og $\mathrm{i}$ det skjulte or virksomme for at vende Landet fra os", og han giver Udtryk for "vor" Vilje og Opgave, nogsaa indadtil helt at tilegne os det Land, vi har arvet fra vore Fædre".

22. Marts. Gaardejer Thorvald Friis i Ejsbøl sælger sin Fædrenegaard til den prøjsiske Regering for 275,000 Mark. Gaarden skal omdannes til Statsdomæne.

24. Marts. Landsretten i Flensborg genindsætter Gaardejer H. Michelsen i Møgeltønder, der af 
nationale Grunde er bleven afsat som Formyader, i sin tidligere Stilling.

24. Marts. Et dansk Konsortium køber Gaarden „Bosholm" ved Brede for 95,000 Mark og hindrer derved, at den falder i den prøjsiske $\mathrm{Re}_{\theta}$ gerings Hænder.

25. Marts. Provinslanddagen beslutter, at Provinsen skal tegne en Forretningsandel paa 50,000 Mark $i$ en planlagt tysk Nybyggerforening for Hertugdømmerne. (Jf. 28. Maj).

28. Marts. Frimenighedskirken i Skærbæk indvies ved en Højtidelighed, som overværes af henved 500 Personer.

29. Marts. Det meddeles, at Regeringsassessor Dr. Dryander er bleven definitivt udnæovnt til Landraad i Haderslev. (Se 1. Oktober 1908).

31. Marts. De danske Kredsdagsmænd i Tønder Kreds nedlægger Indsigelse imod, at der af Kredsen tegnes en Forretningsandel paa 10,000 Mark i det planlagte tyske Nybyggerselskab. (Jf. 28. Maj).

1. April. „Fællesforbundet af kristelige Ungdomsforeninger i Nordslesvig" paabegynder Udgivelsen af et Blad med Navnet "Kristeligt Ungdomsblad ${ }^{4}$ og med Sekretær Kylling i Haderslev som Redaktor.

2. April. Den prøjsiske Regering køber Gaardejer Hubatsches Gaard i Kolsnap for 95,000 Mark for at omdanne den til en Statsdomæne.

5. April. Degn Wind i Hanved, der har været Lærer der i Byen i 32 Aar, faar med faa Dages Varsel Ordre til at tiltræde et Lærerembede i Altona. Om Grunden til denne Tvangsforflyttelse oplyses, at Wind ved Valget af en Kirkeældste i Hanved Sogn ha: stemt for en dansksindet Gaardejers Genvalg.

9. April. To af Pastor Jacobsens Fortyskningsforetagender, som Altyskerne med Administrationens Hjælp har søgt at holde oven Vande, Badestedet "Lakolk“ og „Romø Dampskibsselskab“, erklæres fallit.

11. April. Organist Stange i Tonder spiller ved Slutningen af den danske Gudstjeneste (første Paaskedag) Sangen "Heil dir im Siegerkranz". Dette bliver dog senere af hans foresatte 
stemplet som en Utilborlighed, og Organistew faar en Irettesættelse.

14. April. Bisidderretten i Aabenraa idømmer cand. polit. Kr. R. Thomsen i Aabenraa en Bede paa. 50 Mark, fordi han $i$ en Artikel $i$ "Hejmdal ${ }^{*}$ har sigtet nogle af Dr. Hahns Partifæller, bl. a. Bogholder Roloff ved „Apenrader Tageblatt", for Stemmekøb.

19. April. Landsretten i Flensborg frikender Formanden for Læseforeningen "Enighed" i Tandslet, Gaardejer H. C. Bladt i Lysabild, der af Bisidderretten i Sønderborg or bleven idømt en Bøde par 20 Mark for Overtrædelse af Foreningsloven ved ikke at have anmeldt et Underholdningsmøde, som Foreningen havdehaft den 22. September 1908.

21. April. Bisidderretten i Sønderborg idømmer Redaktøren af "Dybbel-Posten ", A. Svensson, en Bøde paa 20 Mark for ikke at have optaget en Berigtigelse fra Redaktøren af "Sonderburger Zeitung " og en anden paa 120 Mark, fordi et Søndagsblad, der følger med „Dybbol-Posten", har indeholdt ot Digt til det danske Folks Pris. Redaktør Svensson har ganske vist ladet Digtet overtrykke med Sværte for at undgaa Tiltale, men i nogle Eksemplarer menes det alligevel at være læseligt.

30. April. Landsretten i Flenshorg frikender Redaktøren af "Sonderburger Zeitung “, E. Kühler, hvem Bisidderretten i Nordborg har idømt en Bede paa 10 Mark for Fornærmelse imod Journalist. Andreas Grau. IJf. 3. Marts 1.

1. Maj. "Den tyske Forening" vedtager paa et Bestyrelsesmøde en Henvendelse til Magistrater og Kredsdage med Anmodning om at bevilge Penge til "Befrielse af tyske Landmænd og Næringsdrivende fra danske Kreditorer".

8. Maj. "Aabenraa Amts Landboforening “, der i Køllertiden blev erklæret for politisk og siden da. kun har bestaaet af Navn, medens Landboerne i Amtet imidlertid har oprettet Foreningen "Fremad", opløses paa et Mode $i$ Aabenraa efter Deltagernes enstemmige $\mathrm{Be}$ slutning.

11. $\mathrm{Maj}$. „Hejmdal ${ }^{4}$ meddeler, at Frimenigheden paa. Sundeved har faaet Afslag paa en Ansøgning: 
om Tilladelse til at anlægge en egen Kirkegaard ved Frimenighedskirken i Stenderup. Afslaget begrundes med, at der ikke foreligger nogen Trang.

Gaardejer P. Dall i Jels afgaar ved Døden i en Alder af 80 Aar. Han har $i$ en Aarrække været Tillidsmand for flere af vore nationale Foreninger, Medlem af Kirkeforstanderskab, Kommuneraad $\mathrm{m}$. $\mathrm{m}$.

13. Maj. I den prøjsiske Landdag imødegaar Landdagsmand Nis Nissen Dr. Schifferers og Fællers Angreb paa den nordslesvigske Befolkning under Dreftelsen den 27. Februar. Han viser, hvor stort et Ukendskab til Forholdene de har lagt for Dagen, fremfører Anker over Myndighedernes Optræden i Nordslesvig og paataler, at en Del af den tyske Presso jævnlig udspreder anonyme Artikler med Bagvaskelser om Forholdene i Nordslesvig.

19. Maj. Landraad Dryander i Hadersler forbyder Frøken Anna Beier $i$ Brøns at undervise Børn og unge Piger under 18 Aar i Syning og andro Haandarbejder.

21. Maj. Landsretten i Flensborg idømmer Journalist A. Grau i Nordborg og Redaktør A. Svensson i Sønderborg Bøder paa henholdsvis $170 \mathrm{og}$ 20 Mark for et Svar i Dybbol-Posten " paa et af "En gammel Alsinger" undertegnet Indlæg $\mathrm{i}$ "Sonderburger Zeitung“. (Jf. 13. Marts).

22. Maj. "Folkebanken for Als og Sundeved“ i Sonderborg oprettes med en Aktiekapital paa 600,000 Mark. Ved Stiftelsesmødet or der 250 Aktionærer til Stede.

24. Maj. Landsretten i Flensborg dømmer Haderslev Kreds til at levere "Skodborg Sparekasse", som Landraad Becherer paa ulovlig Vis har bortfert, tilbage til Skodborg Kommune.

25. Maj. I det prejsiske Herrehus taler Overborgmester Dr. jur. Todsen fra Flensborg om en dansk Agitation, der i de sidste to Aar or bleven saa grænseløs, at det næsten er umuligt for Tyskerne at opholde sig i Nordslesvig.

28. Maj. Paa et Møde i Kiel oprettes det "slesvigholstenske Bosættelsesselskab", der "efter Grev Rantzaus Sigende vil sege "at rejse en Vold af tyske Kolonister tværs over Nordslesvig". 
Der er sikret Selskabet en Kapital paa 1/a Million Mark, og man har Løfte om Jderligere betydelig Støtte. (Jf. 12. Marts, 25. Marts og 31. Marts).

1. Juni. Den prøjsiske Regering køber Gaarden „Kjerulfsminde" i Hjerndrup med et Areal af 99,5 Hektar og 1950 Mark Nettoudby tte for 135,000 Mark. Den hidtilværende Ejer er tysksindet.

4. Juni. Landsretten i Flensborg ophæver Aabenraa Bisidderrets Dom i Stemmekøbssagen og frikender "Hejmdal"s Medarbejder cand. polit. Kr. R. Thomsen. (Jf. 14. April).

Der oprettes en dansk Foredragsforening i Sønderborg.

6. Juni. "Nordslesvigs Afholdsforening" holder Aarsmøde i Skærbæk. Den tæller nu 28 stedlige Foreninger med 919 Medlemmer.

7. Juni. Den prøjsiske Regering køber Gaardejer Mathias Dalls Gaard i Seggelund med et Areal af 106 Hektar og 2890 Mark Nettoudbytte for 144,000 Mark.

12. og 13. Juni. Det ottende danske Aarsmøde afholdes i Nordborg. (Jf. Sønderj. Aarb. 1909 S. 288).

16. Juni. Lærer H. Lorenzen i Ballum, der har været Lærer i 25', Aar, modtager fra Regeringspræsidenten i Slesvig Meddelelse om, at han er tvangsforflyttet til Byen Schlichting i Nørre-Ditmarsken. Regeringen nægter at angive Grunde for Tvangsforflyttelsen, men Lorenzen erfarer underhaanden, at det er hans Deltagelse i Arbejdet for Afholdssagen samt i Sangstæevnet i Mogeltønder, der har været Aarsag til Forholdsreglen.

17. Jumi. I det tyske Ugeblad „Die christliche Welt"“ paabegynder "En tysk Nordslesviger" (cand. phil. Johannes Tiedje, en Søn af Pastor Tiedje $\mathrm{i}$ Østby) en Række Artikler om Forholdene i Nordslesvig, hvori han ytrer sin Uvilje over det prøjsiske Tvangsstyre og udtaler Onsket om at knytte Nordslesvigerne nærmere til Tyskland ved Kulturens Baand. Cand. Tiedjes Redegørelse udkommer sidst i September som Sæartryk paa Tysk og ved Slutningen af Aaret paa Dansk (ved Prof. Valdemar Ammundsen i Kobenhavn).

21. Juni. Landsretten i Flensborg idømmer Journalist L. P. Christensen ved „Flensborg Avis" en Bøde 
paa 500 Mark for Fornærmelse imod Skolelærer B. Bennetzen i Hokkerup ved at sigte denne for at have drevet Politik og hrugt grove Udtryk over for danske Folks Børn. Af Vidneforhøret fremgaar det bl. a., at Læreren har kaldt danske Forældres Børn „Oprerere" og "revolutionære", men Retten anser ikke Bevisforelsen for fyldestgørende.

26. Juni. I den prøjsiske Provinsregerings "Amtsblatt" findes en Kundgørelse fra Regeringspræsidenten i Slesvig af 9. Juni, hvori der meddeles, at Generalkonsulatet i Hamborg, der hidtil kun har omfattet hamborgsk Statsomraade, nu desuden skal omfatte Hertugdommerne Slesvig, Holsten og Lauenborg samt Hannover (med Undtagelse af nogle Havnebyer) og endelig det oldenborgske Fyrstendømme Lybæk.

30. Juni. Regeringspræsident Dolega v. Koszierowski, Köllerpolitikkens mest udprægede Repræsentant $\mathbf{i}$ den højere Administration, nedlægger sit Embede og forlader Slesvig.

1. Juli. "Nordslesvigs Afholdsforening" paabegynder Udgivelsen af et eget Organ, "Nordslesvigs Afholdsblad", med Journalist J. N. Jensen i Flensborg som Redaktør.

2. Juli. Overforvaltningsretten i Berlin afviser Bankbestyrer Jørgen Møllers Klage over sin Udvisning. I Domsgrundene udtales der, at Møller ikke kan anses for prøjsisk Undersaat, fordi hans Fader, afdøde Gaardejer Filip Møller i Jægerup, ikke staar opført paa de til Aabenraa-Konventionen hørende Lister. (Jf. 26. Februar).

3. Juli. „Den tyske Forening"s Sommergeneralforsamling i Graasten overværes af Hertug Ernst Gynther, der paa det varmeste lover at stotte Foreningens Bestræbelser. Til Gengæld fortæller Rektor Witt fra Sønderborg, at Statssekretær v. Schoen har sagt: "Skaf mig dog denne Hahn fra Halsen".

6. Juli. Overregeringsraad Uckert i Liegnitz udnævnes til Regeringspræsident i Slesvig-Holsten i Dolega v. Koszierowskis Sted. (Jf. 30. Juni). 9. Juli. Gaardejer Thomsen Holm i Billund sælger sin Gaard til Tyskerne for 85,000 Mark.

10.-12. Juli. "Nordslesvigs Fællessangforening" afholder 
sit andet Sangstævne i Haderslev. Der er mødt 297 Sangere, og Besøget par Hoveddagen anslaas til 4000 Mennesker.

12. Juli. Den tyske Rigsdag vedtager en ny Lov om Veteranhjælp. Loven indeholder bl. a. en Hjemmel for den allerede indførte Fremgangsmaade, at den Hædersgave paa 100 . Kroner, som den danske Regering har bevilget de gamle danske Soldater fra Treaarskrigen, kan fradrages; der bliver herefter kun udbetalt dem et Beløb af 7 Mark 50 Penning.

19. Juli. Malermester Holm i Hundslev, der har giftet sig uden at have Bosættelsestilladelse, faar Befaling til at flytte fra Konen.

21. Juli. Sønderborg Provstisynode drofter Andragendet om to ugentlige danske Sprogtimer i de Skoler, hvor der endnu gives dansk Religionsundervisning, og vedtager desangaaende on $R e$ solution til Provinssynoden.

22. Juli. Haderslev Provstisynode holder Møde. Ved Legitimationsprøven nedlægger Synodemedlem for Aastrup, Teglværksejer A. Sabroe, paa et anseligt Antal Lægmænds Vegne Indsigelse mod Konsistoriets Fortolkning af $\S$ 74 i Synodeloven. Da Provst Petersen nægter at lade Hr. Sabroes Forslag om, at Synoden godkender Valget af 3 Lægmænd i Haderslev, komme til Afstemning, forlader 31 dansksindede Medlemmer Synoden. Mødet fortsættes. En skriftlig Indsigelse bliver tagen til Protokols.

28. Juli. Bisidderretten i Sønderborg idømmer Journalist Andreas Grau i Nordborg tre Maaneders Fængsel for Fornærmelse imod Krigerforeningen i Hjortkær. Det drejer sig om en Artikel i "Dybbal-Posten" for 12. Marts, hvori Grau har omtalt, hvorledes den nævnte Krigerforening har skaffet sig Graner til Flagstænger.

1. Avgust. Gaardejer Hans Petersen i Rørkær ved Tønder afgaar ved Døden. (Født 9. Febr. 1845). Han var en stot Personlighed med et stort Maal af Selvstændighed og en stærk Retfærdighedsfølelse. Han har siddet inde med mange baade kirkelige, kommunale, politiske. og økonomiske Tillidshverv; det kan særlig 
fremhæves, at han har været Medlem af Sprogforeningens Tilsynsraad siden Foreningens Stiftelse og Formand for Tønder Landmandskanks Tilsynsraad siden Bankens Oprettelse.

Der meddeles, at Forholdet mellem dansk og tysk Gudstjeneste i 105 nordslesvigske Sognekirker for Tiden er saaledes: I 28 prædikes slet ikke Tysk, i 29 færre end 12 Gange aarlig, i 48 enten 12 eller flere Gange.

2. Avgust. Gaardejer R. P. Clausen i Smedager afgaar ved Døden (Født 15. Januar 1841). Han har haft særdeles mange Tillidshverv: han var Medlem af Herredsraadet, indtil dette ophævedes, Formand for Sognets Fattigvæsen i 21 Aar og Formand for Sognets Sparekasse i over 30 Aar; han var Medlem af Kirkeforstanderskabet, Provstisynoden og Synodeudvalget samt af Kredsdagen og Provinslanddagen; i mange Aar sad han i Bestyrelsen for Aabenraa Amts Landboforening og Vælgerforeningens Tilsynsraad, og indtil sin Død var han Kredsformand for Sprogforeningen. Han var i Besiddelse at grundige Kundskaber og en sund Dømmekraft; samtidig var han en skarp Kritiker og yndede som saadan at fremsætte sin Mening i versificerede private Epistler og til Offentligheden rettede Satirer.

3. Avgust. Aabenraa Provstisynode holder Møde. Bl. a. drøfter man, hvad der kan gøres for at redde den danske Kirkesang fra Undergang. Pastor Friedrichsen fra Øster-Løgum beklager sig over, at Børnene ikke mere kan synge de smukke danske Salmer. Der formuleres et Andragende til Fællessynoden om at foranledige udgivet en ny Melodisamling til Salmebogen for de danske Menigheder. Endvidere føres der en Drøftelse om den danske Religionsundervisning, under hvilken Kredsskolinspektør Mosehuus hævder, at Skolemyndighederne ikke lægger Hindringer $i$ Vejen for denne.

4. August. Det "slesvigholstenske Bosættelsesselskab" begynder sin Virksomhed under Regeringsraad Weidners Ledelse. (Jf. 28. Maj).

16. August. Gaardejer Søren M. Bych i Lunding afgaar ved. Døden, 84 Aar gammel. Han har været 
Kredsdagsinand og siddet inde med et Antal andre baade politiske, kirkelige og økonomiske Tillidshverv.

18. Argust. Bisidderretten i Toftlund frikender Bankbestyrer Jørgen Møller i Skærbæk for Overtrædelse af Udvisningsordren, idet den erklærer ham for prøjsisk Undersaat og altsaa. Udvisningen for ulovlig. Jf. 26. Februar og 2. Juli).

20. Avgust. Henved 60 nordslesvigske Præster nedsætter paa et Møde paa "Missionshotellet “ i Aabenraa et Udvalg til at forberede Dannelsen af en Forenig, der skal tage Stilling til alle særlig nordslesvigske Anliggender, for saa vidt de vedrører Kirke-, Skole- og Folkelivet. (Jf. 20. Septbr.)

En gift dansk Undersaat i Traasbol faar af Amtsforstander Bruhn paa Skovbølgaard Valget imellem at forlade Landet eller at forlade sin Kone. - En anden gift dansk Undersaat sammesteds faar Meddelelse om, at han vil blive udvist, hvis han arbejder hos Danskere.

22. Avgust. Paa et tysk Møde i Tønder retter Kredsens Rigsdagsmand, Dr. I eonhardt, heftige Angreb mod "Den tyske Forening", om hvilken han bl. a. siger, at den er den storste Ulykke for Nordslesvig. Foreningens Formand, Dr. Hahn, er til Stede, men forholder sig tavs.

25. Argust. Gaardejer Jørgen Kjær i Hjartbro sælger sin Gaard til det nslesvigholstenske Bosættelsesselskab" for 88,000 Mark.

Bisidderretten i Rødding idømmer Landmændene H. Hansen i Vester-Lindet og Nielsen i Terp en Bøde paa hver 20 Mark for ved en Ringriderfest at have sunget ${ }_{n} \mathrm{~J} e \mathrm{~g}$ or on simpel Bondemand", "Dengang jeg drog afsted" og "Kong Kristian stod ved højen Mast."

31. Avgust. Tørninglen Provstisynode holder Møde i Gram. Provst Godtfriedsen meddeler, at der paa et for to Aar siden til Konsistoriet indsendt Andragende om to ugentlige danske Sprogtimer i Skolerne or indløbet det Svar, at der ikke kan ændres noget ved Sprogordningen; derimod har Regeringen tilbudt en udvidet Konfirmationsundervisning. 
3. September. Landsretten i Flensborg stadfæster en Bødepaa 120 Mark, som Bisidderretten i Sønderborg har idømt „Dybbøl-Posten"s Redaktor, A. Svensson, for ,Udbredelse af ophidsente Sange". (Jf. 21. April).

6. September. Landsretten i Flenshorg stadfæster den af Bisidderretten i Sønderborg over Journalist A. Grau i Nordborg fældede Dom paa tre Maaneders Fængsel for Fornærmelse imod Krigerforeningen i Hjortkær. (Jf. 28. Juli).

20. September. "Den nordslesvigske Præsteforening ${ }^{4}$ oprettes paa et Møde paa "Missionshotellet ${ }^{\text {" }}$ i Aabenraa med 57 Medlemmer og Pastor Tonnesen i Hoptrup som Formand. (Jf. 20. Avgust).

23. September. Bisidderretten i Haderslev idømmer Rentier Peder Skau paa Bukshave en Bøde paa 50 Mark for Fornærmelse mod Redaktøren af "Schleswigsche Grenzpost", K. Strackerjan. Den sidstnævnte har nemlig for nogen Tid siden fremsat en Paastand om, at Skau har været ivrig virksom for en mod Tyskland rettet dansk Rustning, og denne Sigtelse har Skau saa med et drastisk Udtryk betegnet som usand.

27. Septemher. Vesterhavsbadet "Lakolk“ gaar til Trangssalg. Landraad Dryander byder paa Haderslev Kredssparekasses Vegne 6000 Mark. (Jf. 9. April).

1. Oktober. Landsretten i Flensborg idømmer Rigsdagsmand H. P. Hanssen en Bøde paa 400 Mark, fordi han $i$ en Artikel om Forholdene $i$ de polske Landsdele har indflettet en Bemærkning om „Den tyske Forening ${ }^{4}$ s Agitation. Ved denne Lejlighed maa Landsretsraad Dr. Hahn som edfæstet Vidne indrømme, at han fra Regeringen i Berlin har modtaget en Paamindelse om ikke at volde den udenrigske Politik Vanskeligheder.

5. Oktober. Der afholdes et Møde i Malente-Grenzmühlen, hvor Pastor Schmidt fra Vodder taler om de nordslesvigske Forhold.

9. Oktober. "Nordslesvigs Fællessangforening" holder Aarsmode i Aabenraa. Den omfatter nu 22 Sangforeninger med 400 aktive Sangere.

10. Oktober. „Fællesforbundet af kristelige Ungdomsforeninger i Nordslesvig" holder Aarsmede i 
Vojens. Fællesforbundet, der i Maj 1908 dannedes af 12 smaa Foreninger, tæller nu 32 Foreninger med 660 Medlemmer. Der er $i$ det forløbne Aar blevet afholdt henved 300 Ungdomsmøder.

11. Oktober. Landsretten i Flenshorg ophæver den af Bisidderretten i Toftlund fældede Dom, hvorved Baukbestyrer Jørgen Møller frikendtes for Overtrædelse af en Udvisningsordre, og idømmer ham 1 Dags Fængsel for ulovlig Tilbagevenden. (Jf. 18. Avgust).

14. Ohtober. Bisidderretten i Haderslev idømmer Redaktøren af "Schleswigsche Grenzpost", K. Strackerjan, en Bøde paa 500 Mark for at have kaldt Rigsdagsinand H. P. Hanssen en "Landsforræder". Statsadvokaturen har denne Gang rejst offentlig Tiltale. Straffen sættes imidlertid saa lavt, fordi Retten antager, at den anklagede har ladet sig lede af ,ædle Bevæggrunde".

18.-28. Oktober. Provinssynoden er samlet i Rendsborg. Den 20. Oktober udspinder der sig en større nordslesvigsk Droftelse, hvori ogsaa Tidjes Bog og Præsteforeningen berøres. De danske Synodemedlemmer fremsætter atter med Styrke det gamle Krav om to Timers dansk Sprogundervisning i Skolerne. Paa tysk Side forlanger man til Gengæld flere tyske Gudstjenester. Biskop Kaftan svarer paa Konsistoriets Vegne, at en Forøgelse af dem ikke bør gaa ud over de danske Gudstjenester; Konsistoriet vil vedblivende udtrykkelig hævde den Grundsætning, at Kirken maa handle kirkeligt, den mas saa vidt muligt holdes uden for den nationale Kamp. - Den 27. Oktober forkastes det af Pastor Hansen i Dybbel indbragte Andragende om hos Konsistoriet at udvirke to ugentlige Timers dansk Sprogundervisning $\mathrm{j}$ de nordslesvigske Skoler med alle Stemmer imod 11. - Den 28. Oktober kommer den haderslevske Provstisynodesag til Forhandling. Fællessynoden giver deri Konsistoriet Medhold i Fortolkningen af $\S 74$ i Synodeloven. (Jf. 22. Juli).

21. Oktober. Lærer Lorenzen i Ballum afskediges uden Pension, efter at han den 13. Oktober har nedlagt sit Embede, da Regeringen har nægtet 
at angive Grunde for hans Trangsforflyttelse og at yde ham Afsked med Pension. (Jf. 16. Juni).

22. Ohtober. Bisidderretten i Sønderborg idømmer Redaktøren af "Dybbel-Posten", A. Svensson, to Maaneders Fængsel for Fornærmelse imod Landsretsraad Dr. Hahn. Fornærmelsen findes $i$, at der $i$ en Overskrift i "Dybbel-Posten" er sat en Del. Hærværk mod Hostrup Sogns Forsamlingshus $i$ en vis Forbindelse med Dr. Hahns Agitation.

Landsretten i Flensborg stadfæster on Bøde paa 50 Mark, som Gaardejer Volle Damm i i Jelsskov er bleven idemt af Bisidderretten i Haderslev, fordi han ikke har ladet sin Søn besøge den prøjsiske Skole, efter at Sennen til Paaske 1908 er bleven konfirmeret i Kongeriget.

24. Oktober. Forsamlingshuset i Jejsing indvies.

27. Oltober. Bisidderretten i Aabenraa idømmer Medarbejder ved "Hejmdal", cand. polit. Kr. R. Thomsen en Bode paa 15 Mark for ikke at have optaget en Berigtigelse fra Landdagsmand Dr. Schifferer i Kiel paa Tysk. Efter Bisidderrettens Mening er det berettiget at forlange Eerigtigelser optagne i det tyske Sprog, da vi befinder os $\mathrm{i}$ et tysk Land."

28. Oktober. Rigsretten i Leipzig forkaster den af Journalist L. P. Christensen ved "Flensborg Avis" nedlagte Revision af den flensborgske Landsretsdom i Fornærmelsessagen mod Skolelærer Bennetzen i Hokkorup (Jf. 21. Juni).

29. Oktober. Rebslager Mads Jensen i Haderslev afgaar ved Døden, 70 Aar gammel. Han har gjort sig kendt som Stifter af Nordslesvigs Froavlerforening og som Forfatter af Landbrugsbøger og Smaaskrifter.

31. Oktober. Forsamlingshuset i Norre-Hostrup i Egvad Sogn indvies.

Paa et Møde i Neumünster bryder de Tyskfrisindede i Hertugdemmerne Staven over Dr. Hahn og hans Politik. Bl. a. udtaler de deres Harme over hans, ,fuldstændig ugrundede Angreb paa de frisindede Parlamentarikeres tyske Sindelag.

1. November. Brodersens Enkes Gaard i Klipler sælge til Tyskerne for 44,000 Mark. 
3. November. Apoteker J. A. Wiinsted i Horsens afgaar ved Døden, 79 Aar gammel. Han oprettede i 1863 en Landbrugsskole paa Aagaard i Oversø Sogn, som han derpaa ledede i en Række Aar.

Regeringspræsident Uckert besøger Haderslev Kreds.

6. November. Overlandsretten i Kiel forkaster den af Journalist Andreas Grau i Nordborg nedlagte Revision af den flensborgske Landsrets Dom paa tre Maaneders Fængsel i Flagstangsagen (Jf. 6. September).

Tandlæge J. Lassen i Haderslev afgaar ved Døden (Født 14. Septbr. 1873). Han stillede sig altid beredvillig $\mathrm{i}$ den danske Sags Tjeneste. Bl. a. var han Formand for Kommunalforeningen i Haderslev.

10. November. "Nordslesvigsk Kreditforening “ stiftes paa et Møde i Haderslev med en Andelskapital paa 830,000 Mark, der or fordelte paa rigelig 1400 Andele. Det er Foreningens Formaal at drive Bankforretning til Fremme for Landbrug, Handel og Industri og og derved navnlig at danne on Modvægt mod det slesvigholstenske Bosættelsesselskab. Kreditbanken skal begynde sin Virksomhed den 1. Januar $1910 \mathrm{og}$ have sit Lokale i Haderslev.

Paa et Møde i Tinglev overdrager 58 tyske Mænd og Kvinder det til 12 af de tilstedeværende at forberede Dannelsen af en $n$ Fredsforening", der skal stotte Tyskheden i Nordslesvig ved Oplysning, Selskabelighed o. dsl. (Jf. 1. Decbr.)

15._21. November. Vælgerforeningens social-politiske Kursus afholdes paa "Folkehjem" i Aabenraa.

19. Novemker. Paa et Møde, som „Nordslesvigsk Kreditforenings Tilsynsraad holder i Haderslev, vælges Ejendomskommissionær J. H. Schmidt i Haderslev, Gaardejer Refslund Poulsen paa Skovgaard og Bankassistent J. Schmidt i Haderslev til Direktører for Kreditforeningen. (Jf. 10. November).

26. Novemker. Landsretten i Flensborg stadfæster en Bøde paa 50 Mark, som Bisidderretten i Haderslev har idømt Rentier Peder Skau paa Buks- 
have for Fornærmelse imod Redaktor $\mathrm{K}$. Strackerjan i Haderslev. ((Jf. 23. September.) For Landsretten i Flensborg forhandles en Privatklagesag, hvorunder Redaktøren af "Sonderburger Zeitung“, E. Kühler, ved Bisidderretten i Senderborg er bleven ikendt en Bøde paa 50 Mark for Fornærmelse imod Redaktøren af "Dybbol-Posten, A. Svensson, medens denne paa Kühlers Modklage har faaet en Bøde paa 75 Mark. Sagen ender med Forlig, idet begge tager deres Klage tilbage.

27. November. Bogholder Mogensen hos Brødrene Fink i Aabenraa udvises, fordi han har overværet Indvielsen af Forsamlingshuset i Norre-Hostrup.

„Udvalg for kristelig Virksomhed i Nordslesvig " holder Aarsmode i Hygum. Udvalget har i det sidste Beretningsaar ladet afholde henved 90 Møder. I Aarets Løb har det ladet uddanne henved 40 Sygeplejersker, hvoraf dog kun de 19 er i Virksomhed.

28. November. Landraad Dryander i Haderslev nagter Arbejdsmand Nikolajsen i Sommersted Bosæattelsestilladelse.

29. Nowember. Landsretten i Flensborg stadfæster en Bøde paa 500 Mark, som Bisidderretten i Haderslev har idemt Redaktoren af "Schleswigsche Grenzpost ${ }^{*}, \mathrm{~K}$. Strackerjan, for Fornxrmelse imod Rigsdngsmand H. P. Hanssen (Jf. 14. Oktober). I Domsgrundene tales om den anklayedes, ædle patriotiske Bevæggrunde" og Hanssens "retsvitterligt illoyale og moralsk tvivlsomme Optræden."

30. November. Ved Handelskammervalget i Haderslev gaar Danskerne af med Sejren.

1. December. Den tyske "Fredsforening ${ }^{\text {" oprettes paa et }}$ Mode i Tinglev med ca. jo Medlemmer og med Pastor Schmidt i Vodder som Formand. (Jf. 10. Novbr.)

3. December. Foredragsforeningen for Nustrup med flere Sogne holder 25 Aars Jubilæum.

4. Decembor. Paa "Den tyske Forenings" Generalforsamling i Tonder meddeles der, at Medlemsantallet er steget til 11,000 , d. e. 2000 flere end i Fjor. I Tonder Kreds er der siden Agitationens Begyndelse vundet 1000 Til. 
hængere. I Aarets Lob er der blevet oprettet stedlige Afdelinger i Tender, Bylderup, Medelby, Læk og Viding Herred samt i Holsten.

5. December. Frimenighedskirken i Rødding indvies ved en Højtidelighed, hvori der deltager ca. 600 Personer.

10. December. Tidligere Gaardejer Rasmus Hansen i $\mathrm{Ka}$ strup afgaar ved Døden i Strandelhjørn. (Født 4. Novbr. 1828). Som Medlem af Kirkepræsentationen, Provstisynoden og Sy nodeudvalget har han trofast værnet om det danske Sprog i Kirke og Skole ligesom han ogsaa ellers har været med til baade mundtlig og skriftlig at kæmpe for Folkets Ret. Han sad inde med gode Kundskaber og et ypperligt Lune.

11. December. En Tjenestekarl paa Tornumgaard og en Skræddersvend i Hjerting udvises, fordi de har været med i Forsainlingshuset.

Der nægtes Landmand Fr. G. Hansen fra Bodum Bosættelsestilladelse.

13. December. Landsrotten i Flensborg stadfæster en Fængselsstraf paa to Maaneder, som Bisidderretten i Senderborg har idømt Redakteren af "Dybbal-Posten", A. Svensson, for Fornærmelse imod Dr. Hahn. (Jf. 22. Oktober). Landsretten fastslaar, at Dr. Hahn, der var optraadt med megen Takt og Forsigtighed, or ,værdig til særligt Værn fra Rettens Side".

15. December. Den Bosøttelsestilladelse, som Købmand Fr. Colfack i Rødding har faaet, tages tilbage.

17. December. Kniplingshandler Dethlef Hansen i Mogeltonder, den sidste Kniplingskræmmer paa Vestkysten, afgaar ved Døden, 78 Aar gammel.

18. December. To af Kobmand Colfacks Folk i Rødding udvises.

21. December. Gaardejer J. Schmidt i Øster-Terp sælger sin Gaard til det slesvigholstenske Bosættelsesselskab" for 42,000 Mark.

22. December. Gaardejer Kr. Thomsen i Bredebro sælger sin Gaard til den projsiske Regering for 96,000 Mark.

Dampskibet „Kanal" forliser ved Aarøsund; fem Mennesker drukner. 
23. December. Landsretten i Flensborg anerkender Maskinist Christoffer Fischer, Søn af Kaptejn Fischer i Aabenraa, som prøjsisk Undersaat; Kaptejn Fischer afhøres som edfæstet Vidne.

27. December. Journalist Andreas Grau i Nordborg tiltræder sin 3 Maaneders Fængselsstraf i Neumünster. (Jf. 6. Novbr.)

29. December. Rigsdagsmand Dr. Leonhardt oplyser, at den tyske Regering har tilskyndet Gehejmeraad Juirgensen til at skrive Artiklen mod "Den tyske Forening" i „Kölnische Zeitung" (Jf. 5. Oktober 1908).

Sognepræsten i Bolderslev prever paa at indfere tysk Salmesang ved den danske Gudstjeneste, men Kirkeforstanderskabet hindrer det.

N. $A$. 
" 




\section{"Sønderjydske Aarbøger" udgivne af}

\section{*. P. F̧anssen-Norremolle, P. Skau og Nikolaj findersen}

begyndte at udkomme 1889 og har siden $i$ en Raxke forskellige Bidrag skildret Slesvigs Historie, Land, Folk og Minder og har i politiske og statistiske Oversigter belyst Nordslesvigernes Kamp for Bevarelsen af dansk Sprog og Kultur.

,Sonderjydske Aarboger"6 vil som hidtil behandle alle nordslesvigske Sporgsmaal i videste Omfang, Historie og Politik, Sprog og Folkeminder, Naturforhold og Landoknnomi. De vil desuden bringe Skildringer af andre Nationalitetskampe i Fortid og Nutid og Druftelse af saadanne Forhold, der direkte eller indirekte staar i Forbindelse dermed.

"Sønderjydske Aarboger" udkommer to Gange aarligt i Hiefter paa tilsammen omtr. 20 Ark. Subskription modtages i allo Boglader i Slesvig, Danmark, Norge og Sverige og i (iyldendalske Boghandel, Horedkommissionen for de tre nordiske Lande. Prisen er 4 Kroner Aargangen; fur Medlemmer af danske Foreninger i Nordslesvig 3 Mark.

\section{Indhold af Aargang 1910.}

Robert Neiiendam: Dansk Theuterhistorie i Nordslesvig 1864-1910 . . . . . Side 1-81

$\mathrm{Chr}$. $\mathrm{H} \ddot{\mathrm{ub}} \mathrm{b}$ e: Det nordslesvigske Pengevæsen n 82-121

F. Ohrt: Fra Ostgrænsen (Træk af Nationalitetskampen mellem Finner og Russere) n 122-167

H. Weitemeyer: Af Præsteindberetninger fra Ribe Stift . . . . . . . . . . n 158-222

Joh annes Lind bæk: Oversigt over historisk Litteratur fra Aarene 1904-1907 vedrorende Sonderjylland.

Tha de Petersen: Det danske Aarsmøde 1910 " 271-28: N, A.: Dagshistorie 1909 . . . . . . . . n 283-301 